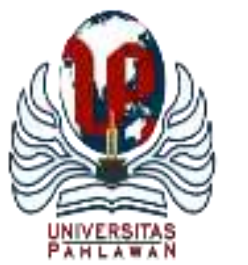

Edukatif : Jurnal Ilmu Pendidikan Volume 4 Nomor 1 Tahun 2022 Halm 141 - 153 EDUKATIF: JURNAL ILMU PENDIDIKAN

Research \& Learning in Education

https://edukatif.org/index.php/edukatif/index

\title{
Implementasi Manajemen Resiko dalam Peningkatan Efektivitas Pembelajaran di Sekolah Menengah Kejuruan
}

\author{
Suyitno \\ STIE Indonesia Malang \\ E-mail : drsuyitno@yahoo.co.id
}

\begin{abstract}
Abstrak
Penelitian ini bertujuan untuk mengetahui tentang penerapan manajemen risiko di SMK Mondoroko yang meliputi penentuan konteks risiko, melakukan risk assessment yang terdiri dari risk identification, risk analysis, serta risk evaluation dan penentuan mitigasi pada proses pembelajaran. Penelitian ini menggunakan pendekatan metode kualitatif dengan tataran analisis eksploratif yang telah disesuaikan dengan tahapan pada proses manajemen risiko dari kerangka ISO 31000:2018 tentang Standar Manajemen Risiko. Pengumpulan data dilakukan dengan observasi, dokumentasi dan wawancara dengan expert sampling. Hasil penelitian menunjukkan bahwa analisis risiko pada proses pembelajaran di SMK Mondoroko ditinjau dari 4 kategori yakni kategori siswa, kategori guru, kategori kurikulum dan kategori lingkungan akademik. Berdasarkan keempat kategori tersebut memunculkan 29 risiko yang diidentifikasi dalam proses penilaian risiko dan berdampak signifikan secara berurutan adalah dari kategori kurikulum dilakukan penanganan melalui sinkronisasi kurikulum link and match dengan DUDI, kategori siswa dilakukan penanganan melalui penerapan pembelajaran metode work based learning (WBL), kategori guru dilakukan penanganan melalui penyelenggaraan program guru magang industri dan kategori lingkungan akademik dilakukan penanganan melalui pengelolaan dan pengadaan peralengkapan bengkel yang sesuai dengan teknologi terkini.
\end{abstract}

Kata Kunci: implementasi, manajemen resiko, efektivitas pembelajaran

\begin{abstract}
This study aims to find out about the application of risk management at SMK Mondoroko which includes determining the risk context, conducting a risk assessment consisting of Risk Identification, Risk analysis, and Risk Evaluation and determining mitigation in the learning process. This study uses a qualitative method approach with an exploratory analysis level that has been adapted to the stages in the risk management process from the ISO 31000:2018 framework on Risk Management Standards. Data was collected by observation, documentation and interviews with expert sampling. The results showed that risk analysis in the learning process at SMK Mondoroko was viewed from 4 categories, namely the student category, the teacher category, the curriculum category and the academic environment category. Based on these four categories, 29 risks were identified in the risk assessment process and had a significant impact sequentially, namely the curriculum category was handled through link and match curriculum synchronization with DUDI, the student category was handled through the application of work based learning (WBL) methods, the teacher category handling is carried out through the implementation of the industrial apprentice teacher program and the academic environment category is handled through the management and procurement of workshop equipment in accordance with the latest technology.
\end{abstract}

Keywords: implementation, risk management, learning effectiveness

Copyright (c) 2022 Suyitno

$\triangle$ Corresponding author

Email : drsuyitno@yahoo.co.id

DOI : https://doi.org/10.31004/edukatif.v4i1.1768

ISSN 2656-8063 (Media Cetak)

ISSN 2656-8071 (Media Online)

Edukatif : Jurnal Ilmu Pendidikan Vol 4 No 1 Tahun 2022 p-ISSN 2656-8063 e-ISSN 2656-8071 
142 Implementasi Manajemen Resiko dalam Peningkatan Efektivitas Pembelajaran di Sekolah Menengah Kejuruan - Suyitno

DOI: https://doi.org/10.31004/edukatif.v4i1.1768

\section{PENDAHULUAN}

Dalam kondisi modern, masalah dalam menemukan dan membentuk sistem manajemen risiko yang efektif dalam keseluruhan proses manajemen menjadi prioritas di bidang pendidikan. Hal ini diperlukan untuk membuat keputusan yang efektif pada organisasi proses pendidikan. Akibatnya, ada kebutuhan obyektif untuk menggunakan pendekatan berbasis risiko untuk manajemen, yang mencakup seperangkat metode dan alat untuk mengidentifikasi risiko, menilai dan menganalisisnya, serta mengembangkan strategi dan taktik untuk dampak, diikuti dengan memantau statusnya (Korechkov, 2021).

Manajemen risiko merupakan proses untuk mengidentifikasi, menilai, dan mengendalikan ancaman terhadap sumberdaya organisasi. Risiko ini berasal dari berbagai sumber termasuk ketidakpastian keuangan, kewajiban hukum, masalah teknologi, kesalahan manajemen strategis, kecelakaan dan bencana alam. Program manajemen risiko yang berhasil membantu organisasi mempertimbangkan berbagai risiko yang dihadapinya. Manajemen risiko juga memeriksa hubungan antara risiko dan dampak berjenjang yang dapat mereka miliki terhadap tujuan strategis organisasi.

Pendekatan holistik untuk mengelola risiko ini kadang-kadang digambarkan sebagai manajemen risiko institusi karena penekanannya pada mengantisipasi dan memahami risiko di seluruh organisasi. Selain fokus pada ancaman internal dan eksternal, manajemen risiko organisasi menekankan pentingnya mengelola risiko positif. Risiko positif adalah peluang yang dapat meningkatkan nilai bisnis atau, sebaliknya, merusak organisasi jika tidak diambil. Tujuan dari setiap program manajemen risiko bukanlah untuk menghilangkan semua risiko tetapi untuk melestarikan dan menambah nilai perusahaan dengan membuat keputusan risiko yang cerdas.

Dengan demikian, program manajemen risiko harus terjalin dengan strategi organisasi. Untuk menghubungkan mereka, pemimpin manajemen risiko pertama-tama harus menentukan selera risiko organisasi yaitu, jumlah risiko yang bersedia diterima untuk mewujudkan tujuannya. Tugas beratnya adalah untuk kemudian menentukan risiko mana yang sesuai dengan selera risiko organisasi dan mana yang memerlukan kontrol dan tindakan tambahan sebelum dapat diterima dan beberapa risiko akan diterima tanpa tindakan lebih lanjut yang diperlukan. Sehingga resiko lainnya akan dikurangi, dibagikan dengan atau dialihkan ke pihak lain, atau dihindari sama sekali.

Manajemen risiko dalam organisasi pendidikan adalah sistem yang kompleks untuk mengumpulkan, mentransmisikan, dan memproses sejumlah besar informasi dan kemudian membuat keputusan manajemen yang tepat (Spichak et al., 2020). Sampai saat ini, semua risiko yang timbul dalam perusahaan dianggap dan dipelajari sebagai elemen terpisah yang tidak terkait, yang membuat tidak mungkin untuk membandingkannya satu sama lain dan menganalisis hasil yang diperoleh. Dalam beberapa tahun terakhir, pendekatan terhadap proses manajemen risiko telah berubah secara signifikan, yang segera mengarah pada pembentukan model manajemen risiko baru yang secara komprehensif mempertimbangkan risiko semua departemen dan aktivitas organisasi pendidikan (Aven, 2016).

Selain itu, dalam semua definisi risiko, ada dua elemen umum, ketidakpastian dan kerugian. Signifikansi dari ketidakpastian dalam risiko menyiratkan bahwa hasil dari suatu peristiwa selalu dipertanyakan. Jika ada risiko, maka selalu ada dua kemungkinan hasil. Jika ada kepastian besar bahwa kerugian akan terjadi, maka tidak ada risiko atau besarnya tidak signifikan. Demikian juga, jika hasil dari suatu peristiwa pasti, tidak ada risiko dalam kasus itu. Risiko adalah kombinasi dari kemungkinan dan konsekuensi dari suatu peristiwa yang merugikan. Dengan demikian, perlu adanya pengelolaan risiko yang menjadi hal penting bagi suatu organisasi, termasuk organisasi sekolah karena kegiatan pendidikan tidak terlepas dariadanya risiko yang dapat mengganggu keberlangsungan pencapaian tujuan pendidikan di sekolah. Lembaga pendidikan sebagaimana halnya dengan organisasi lainnya pasti akan selalu berhadapan dengan risiko, baik itu risiko yang berasal dari dalam maupun dari luar instansi pendidikan. Banyaknya permasalahan 
143 Implementasi Manajemen Resiko dalam Peningkatan Efektivitas Pembelajaran di Sekolah Menengah Kejuruan - Suyitno

DOI: https://doi.org/10.31004/edukatif.v4i1.1768

yang membelenggu dunia pendidikan mulai dari pengelolaan asset dan keuangan oleh instansi pendidikan hingga rendahnya mutu lulusan yang dihasilkan dari setiap jenjang sekolah kesemuanya membawa efek negatif bagi dunia pendidikan di Indonesia.

Untuk dapat menghadapi persaingan lokal dan global, sebuah lembaga pendidikan harus mampu menyediakan program yang sesuai dengan kebutuhan pasar, unggul dalam pengembangan ilmu pengetahuan, memiliki pengendalian internal yang efektif, mampu mengelola potensi risiko dan memiliki tata kelola perusahaan yang baik. Sebuah sekolah membutuhkan suatu sistem yang mampu menjamin berjalannya proses akuntabilitas melalui pengendalian internal yang efektif dalam organisasi pendidikan. Sistem pengendalian intern yang andal dan efektif tidak hanya diperlukan dan ditujukan bagi organisasi yang berorientasi profit tetapi juga bagi organisasi nonprofit termasuk sekolah. Melalui penerapan pengendalian internal yang andal, perguruan tinggi akan mampu secara efektif dan efisien meningkatkan pencapaian tujuan organisasi dan beradaptasi dalam lingkungan operasional organisasi. Sehingga semua itu menuntut untuk melakukan antisipasi dari awal dalam menghadapi risiko agar risiko yang dihadapi tidak menimbulkan sebuah kerugian. Risiko yang ada merupakan sesuatu yang tidak dapat dihindari. Mengingat globalisasi dan internasionalisasi bisnis pendidikan, penting untuk mengakui kerangka kerja manajemen risiko lain di seluruh dunia. Hasil dari kerangka kerja manajemen risiko lembaga pendidikan bisa sangat beragam untuk satu organisasi dengan organisasi lainnya (Pradesa et al., 2021), tetapi salah satu hal terpenting dari risiko yang bisa ditarik kesamaan diantara perguruan tinggi adalah tentang kurikulumnya, terutama dikaitkan dengan kesesuaian dengan learning outcome atau profil lulusan (Al-Jundi \& Ahmad, n.d.).

Sementara berkaitan dengan manajemen resiko sebagaimana menjadi kajian utama dalam penelitian ini, SMK Mondoroko telah menerapkan tindakan manajerial dalam peningkatan efektifitas operasional pendidikan sejak awal utamanya di bidang pengajaran. Pengajaran erat kaitannya dengan sumber daya manusia karena, pada bidang pengajaran keberhasilan suatu sekolah ditunjukkan melalui kualitas dari lulusan yang ada. Akan tetapi, dalam pelaksanaan program pengajaran yang dilakukan oleh SMK Mondoroko didapatkan bahwa adanya upaya penyesuaian kurikulum setiap pergantian tahun ajaran baru yang mengakibatkan program pengajaran sering berubah karena banyak mata pelajaran yang kurang sesuai dengan implementasi yang diharapkan oleh lapangan kerja, namun oleh karena perkembangan teknologi yang demikian cepat memiliki konsekuensi pada implementasi kurikulum yang telah disesuaikan tersebut. Dengan demikian perlulah penerapan manajemen risko dalam bidang pengajaran agar dalam hal merancang metode pembelajaran yang dilakukan oleh guru tidak menimbulkan dampak risiko yang dapat mempengaruhi kualitas belajar siswa.

Berdasarkan uraian di atas, maka penelitian ini berupaya mengkaji dan mengeksplorasi penerapan manajemen risiko di SMK Mondoroko yang meliputi penentuan konteks risiko, melakukan risk assessment yang terdiri dari risk identification, risk analysis, serta risk evaluation dan penentuan mitigasi pada proses pembelajaran. Penelitian ini menarik untuk dilakukan karena selama ini penelitian tentang penerapan menajemen risiko lebih sering dilaksanakan di perusahaan dibandingkan di lembaga pendidikan. Harapan dari penelitian ini adalah dapat mengetahui tentang penerapan manajemen risiko khususnya dalam bidang pembelajaran yang ada di SMK Mondoroko agar dapat mendukung mencapai visi, misi, serta tujuan yang telah direncanakan.

\section{METODE PENELITIAN}

Penelitian ini dilaksanakan di SMK Mondoroko dengan menggunakan metode kualitatif dengan tataran analisis eksploratif (Suyitno, 2018) yang telah disesuaikan dengan tahapan pada proses manajemen risiko dari kerangka ISO 31000:2018 tentang Standar Manajemen Risiko. Pengumpulan data pada penelitian ini diperoleh dari wawancara dengan expert sampling yakni Kepala Sekolah, Wakil Kepala Sekolah, Kepala Bengkel dan Kepala Unit Penjaminan Mutu Internal Sekolah. Tahapan yag dilakukan dalam penelitian ini 
144 Implementasi Manajemen Resiko dalam Peningkatan Efektivitas Pembelajaran di Sekolah Menengah Kejuruan - Suyitno

DOI: https://doi.org/10.31004/edukatif.v4i1.1768

diawali dengan penentuan konteks dari risiko, kemudian risk assessment yang terdiri dari 3 bagian yakni risk identification, risk analysis, serta risk evaluation dan diakhiri dengan risk mitigation.

Penetapan kriteria penilaian risiko terdiri atas penentuan skala dampak risiko, penentuan skala kemungkinan terjadinya risiko, serta penentuan level risiko. Penelitian ini dibatasi pada rangkaian proses manajemen risiko sampai dengan penilaian risiko untuk sebuah institusi. Proses penilaian risiko tersebut disesuaikan dengan standar manajemen risiko ISO 31000:2018, dengan harapan agar hasil penelitian ini bernilai informatif dan praktis terkait pengelolaan risiko lembaga pendidikan utamanya Sekolah Menengah Kejuruan (SMK). Proses analisis risiko ini seringkali dituangkan dalam bentuk matriks risiko yang terdiri dari matriks kemungkinan dan dampak dengan besaran nilainya masing-masing. Adapun nilai risiko adalah kombinasi diantara kemungkinan dan dampak dari sebuah risiko yang telah diidentifikasi mengacu pada tabel berikut.

Tabel 1. Skala Frekuensi Kejadian Risiko

\begin{tabular}{ccc}
\hline Skala & Frekuensi Kejadian & Kategori \\
\hline 5 & Dapat terjadi setiap saat $(>7$ kali). & Hampir Pasti \\
\hline 4 & Sering terjadi (6-7 kali). & Sering \\
\hline 3 & Pernah terjadi (4-5 kali). & Biasa \\
\hline 2 & Jarang (2-3 kali) & Rendah \\
\hline 1 & Hampir tidak pernah, sangat jarang terjadi (0-1 kali). & Sangat Rendah \\
\hline
\end{tabular}

Tabel 2. Skala Severitas Kejadian Risiko

\begin{tabular}{ccc}
\hline Skala & Tingkat Dampak Risiko & Kategori \\
\hline 1 & Dampak risiko tidak terasa sama sekali & Sangat rendah \\
\hline 2 & Dampak risiko sedikit tidak terasa & Rendah \\
\hline 3 & Dampak risiko terasa biasa & Biasa \\
\hline 4 & Dampak risiko terasa signifikan & Tinggi \\
\hline 5 & Dampak risiko terasa sangat signifikan & Katastropik \\
\hline
\end{tabular}

Tabel 3. Tingkat Risiko dan Aksi yang diperlukan

\begin{tabular}{ll}
\hline Tingkat Risiko & Aksi yang diperlukan \\
\hline Extreme risk & Perlu dilakukan aksi yang secepat mungkin \\
\hline High risk & Diperlukan perhatian manajemen tingkat senior \\
\hline Moderate risk & Tanggung jawab manajemen harus diperhatikan kembali \\
\hline Low risk & Diatur oleh prosedur rutin \\
\hline & Sumber: (Peng, Z., 2015)
\end{tabular}

\section{HASIL DAN PEMBAHASAN PENELITIAN}

\section{Indentifikasi resiko}

Identifikasi risiko yang mengacu pada hasil proses bisnis dengan identifikasi yang diperoleh dari hasil wawancara yang dilakukan dengan Kepala Sekolah dan Wakil Kepala Sekolah SMK Mondoroko. Dari hasil wawancara yang dilakukan didapatkan risiko dari sistem pengajaran yang berpotensi menyebabkan kegagalan dipengaruhi oleh guru, siswa, kurikulum, serta lingkungan akademik yang ada pada SMK Mondoroko. Identifikasi risiko yang berpotensi bisa menyebabkan kegagalan pada sistem pengajaran dan digambarkan menggunakan pendekatan analisis sebab akibat (fishbone diagram) seperti pada gambar 1. 
145 Implementasi Manajemen Resiko dalam Peningkatan Efektivitas Pembelajaran di Sekolah Menengah Kejuruan - Suyitno

DOI: https://doi.org/10.31004/edukatif.v4i1.1768

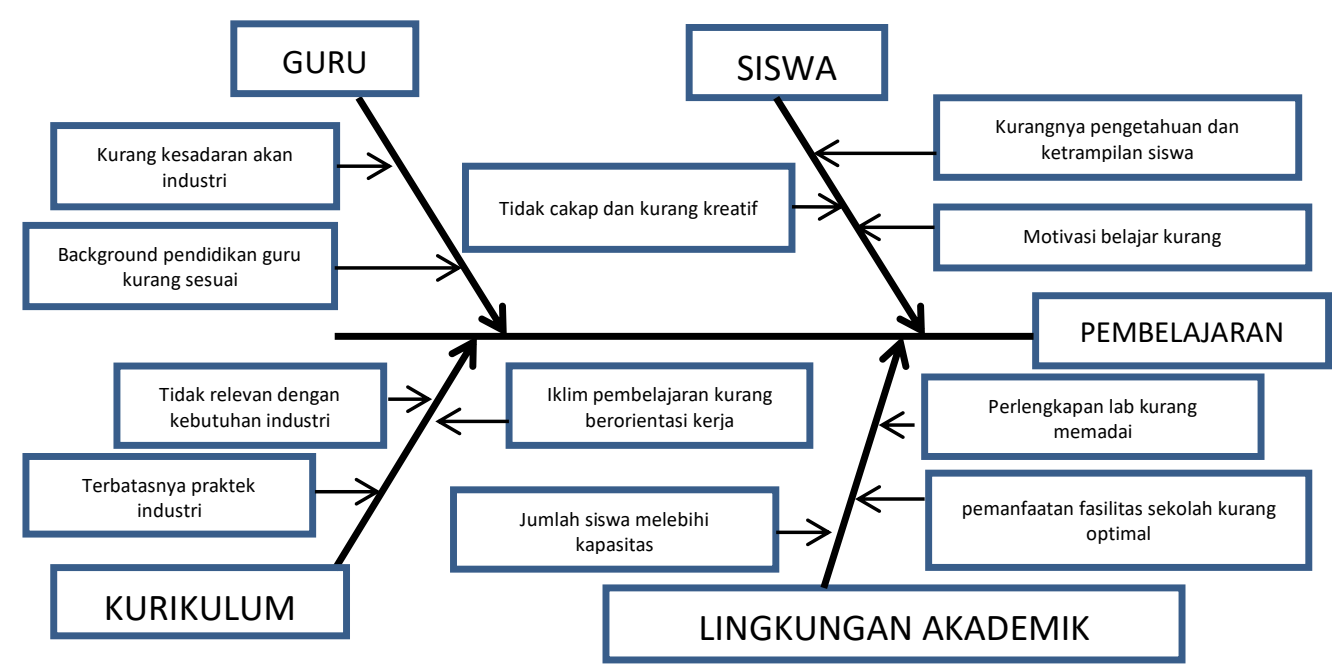

Gambar 1. Diagram sebab akibat (fishbone diagram)

Pada tahap ini pula setiap penyebab dari sumber risiko yang terdapat pada sistem pengajaran dikelompokkan sesuai dengan keterlibatan risiko yang dapat berpotensi mempengaruhi kegagalan dari penerapan sistem pengajaran yang diterapkan oleh SMK Mondoroko. Setelah mengetahui sumber risikoyang ada pada sistem pengajaran, maka setiap sumber risiko yang ada selanjutnya dilakukan analisis serta penjabaran mengenai dampak risiko menurut kesesuaian kelompok dari sumber risiko. Adapun hasil identifikasi risiko nampak pada tabel 4 sebagai berikut.

Tabel 4. Identifikasi Risiko

\begin{tabular}{|c|c|c|}
\hline Kategori & Identifikasi Risiko & Dampak \\
\hline \multirow[t]{9}{*}{ Siswa } & \multirow{3}{*}{$\begin{array}{l}\text { Tidak cakap dan kurang } \\
\text { kreatif }\end{array}$} & Tidak mampu bersaing di dunia kerja \\
\hline & & $\begin{array}{l}\text { Tidak sesuai dengan skill yang di butuhkan } \\
\text { oleh industri }\end{array}$ \\
\hline & & Prestasi akademik siswa rendah \\
\hline & \multirow{3}{*}{$\begin{array}{l}\text { Kurangnya pengetahuan dan } \\
\text { ketrampilan siswa }\end{array}$} & Prestasi akademik siswa rendah \\
\hline & & $\begin{array}{l}\text { Tidak sesuai dengan skill yang di butuhkan } \\
\text { oleh industri }\end{array}$ \\
\hline & & Tidak siap kerja \\
\hline & \multirow[t]{3}{*}{ Motivasi belajar kurang } & Prestasi akademik rendah \\
\hline & & Kesulitan memahami materi pelajaran \\
\hline & & Kegagalan dalam proses pendidikan \\
\hline \multirow[t]{4}{*}{ Guru } & \multirow{2}{*}{$\begin{array}{lll}\text { Kurang } & \text { kesadaran } \\
\text { industri } & & \end{array}$} & Melakukan pembelajaran menekankan teori \\
\hline & & $\begin{array}{l}\text { Memberikan materi yang tidak relevan } \\
\text { dengan tehnologi terkini }\end{array}$ \\
\hline & \multirow[t]{2}{*}{$\begin{array}{l}\text { Background pendidikan guru } \\
\text { kurang sesuai }\end{array}$} & $\begin{array}{l}\text { Tidak menguasai materi yang mestinya } \\
\text { disajikan }\end{array}$ \\
\hline & & Motivasi guru dalam mengajar berkurang \\
\hline \multirow[t]{3}{*}{ Kurikulum } & \multirow[t]{3}{*}{$\begin{array}{lr}\text { Tidak } & \text { relevan } \\
\text { kebutuhan industri }\end{array}$} & $\begin{array}{l}\text { Tidak sesuai dengan skill yang di butuhkan } \\
\text { oleh industri }\end{array}$ \\
\hline & & Kepuasan peserta didik rendah \\
\hline & & Lulusan tidak siap kerja \\
\hline
\end{tabular}




\begin{tabular}{|c|c|c|}
\hline Kategori & Identifikasi Risiko & Dampak \\
\hline & \multirow[t]{3}{*}{ Terbatasnya praktek industri } & Siswa memiliki keterampilan yang rendah \\
\hline & & $\begin{array}{l}\text { Siswa memiliki adaptasi dunia kerja yang } \\
\text { rendah }\end{array}$ \\
\hline & & Citra sekolah menurun \\
\hline & \multirow{3}{*}{$\begin{array}{l}\text { Iklim pembelajaran kurang } \\
\text { berorientasi kerja }\end{array}$} & Motivasi belajar siswa rendah \\
\hline & & Tidak menumbuhkan lulusan siap kerja \\
\hline & & $\begin{array}{l}\text { Pembelajaran tidak menumbuhkan jiwa } \\
\text { kewirausahaan }\end{array}$ \\
\hline \multirow{7}{*}{$\begin{array}{l}\text { Lingkungan } \\
\text { Akademik }\end{array}$} & \multirow{2}{*}{$\begin{array}{lll}\text { Jumlah } & \text { siswa } & \text { melebihi } \\
\text { kapasitas } & & \end{array}$} & Proses pembelajaran tidak efektif/kondusif \\
\hline & & $\begin{array}{l}\text { Siswa akan mengalami kesulitan dalam } \\
\text { belajar }\end{array}$ \\
\hline & \multirow{3}{*}{$\begin{array}{l}\text { Perlengkapan } \\
\text { laboratorium/bengkel } \\
\text { memadai }\end{array}$} & $\begin{array}{l}\text { Siswa akan mengalami kesulitan dalam } \\
\text { belajar praktek }\end{array}$ \\
\hline & & $\begin{array}{l}\text { Tidak sesuai dengan skill yang di butuhkan } \\
\text { oleh industri }\end{array}$ \\
\hline & & Proses pembelajaran tidak efektif \\
\hline & \multirow{2}{*}{$\begin{array}{l}\text { Pemanfaatan fasilitas sekolah } \\
\text { kurang optimal }\end{array}$} & Kegiatan akademik siswa terganggu \\
\hline & & Motivasi belajar siswa menurun \\
\hline
\end{tabular}

\section{Analisis Resiko}

Pada langkah ini dilakukan penilaian pada kolom risk level didapatkan dari kolom severity berdasarkan tingkat keparahan risiko yang ada pada SMK Mondoroko dan kolom occurrence berdasarkan tingkat probabilitas kejadian yang mungkinkan terjadi yang nantinya kemungkinan dapat mengakibatkan kegagalan dalam pengajaran yang dilakukan oleh SMK Mondoroko. Penentuan penilaian pada kolom risk level didasarkan pada hasil nilai rata-rata didapatkan dari wawancara yang dilakukan dengan expert judgment dan pertimbangan dari peneliti (self judgment). Hasil dari analisis risiko seperti nampak pada table 5 berikut ini.

Tabel 5. Tabel Penilaian Risiko

\begin{tabular}{|c|c|c|c|c|c|c|c|}
\hline $\begin{array}{c}\text { Desai } \\
\mathbf{n}\end{array}$ & $\begin{array}{l}\text { Functi } \\
\text { on }\end{array}$ & $\begin{array}{c}\text { Potential Failure } \\
\text { Mode }\end{array}$ & $\begin{array}{c}\text { Potential Failure } \\
\text { Effect }\end{array}$ & $\begin{array}{l}\text { Se } \\
\text { ver } \\
\text { ity }\end{array}$ & $\begin{array}{c}\text { Potential Causes of } \\
\text { Failure }\end{array}$ & $\begin{array}{c}\text { Occu } \\
\text { rren } \\
\text { ce }\end{array}$ & $\begin{array}{c}\text { Risk } \\
\text { Lev } \\
\text { el }\end{array}$ \\
\hline \multirow{3}{*}{$\mathrm{R} 1$} & \multirow{8}{*}{ Siswa } & \multirow{3}{*}{$\begin{array}{l}\text { Tidak cakap dan } \\
\text { kurang kreatif }\end{array}$} & $\begin{array}{l}\text { Tidak mampu } \\
\text { bersaing di dunia } \\
\text { kerja }\end{array}$ & 3 & \multirow{3}{*}{$\begin{array}{c}\text { Kurangnya berlatih } \\
\text { dan belajar dengan } \\
\text { metode work based } \\
\text { learning (WBL) }\end{array}$} & \multirow{3}{*}{2} & 6 \\
\hline & & & $\begin{array}{l}\text { Tidak sesuai } \\
\text { dengan skill yang } \\
\text { di butuhkan oleh } \\
\text { industri }\end{array}$ & 4 & & & 8 \\
\hline & & & $\begin{array}{l}\text { Prestasi akademik } \\
\text { siswa rendah }\end{array}$ & 3 & & & 6 \\
\hline \multirow{3}{*}{$\mathrm{R} 2$} & & \multirow{3}{*}{$\begin{array}{c}\text { Kurangnya } \\
\text { pengetahuan dan } \\
\text { ketrampilan siswa }\end{array}$} & $\begin{array}{l}\text { Prestasi akademik } \\
\text { siswa rendah }\end{array}$ & 3 & \multirow{3}{*}{$\begin{array}{c}\text { Kurangnya } \\
\text { ketertarikan pada } \\
\text { materi pelajaran baik } \\
\text { teori maupun praktek }\end{array}$} & \multirow{3}{*}{2} & 6 \\
\hline & & & $\begin{array}{l}\text { Tidak sesuai } \\
\text { dengan skill yang } \\
\text { di butuhkan oleh } \\
\text { industri }\end{array}$ & 4 & & & 8 \\
\hline & & & Tidak siap kerja & 4 & & & 8 \\
\hline \multirow[t]{2}{*}{$\mathrm{R} 3$} & & Motivasi belajar & $\begin{array}{l}\text { Prestasi akademik } \\
\text { rendah }\end{array}$ & 3 & \multirow{2}{*}{$\begin{array}{c}\text { Kurangnya minat } \\
\text { belajar siswa }\end{array}$} & \multirow[t]{2}{*}{2} & 6 \\
\hline & & & Kesulitan & 3 & & & \\
\hline
\end{tabular}


147 Implementasi Manajemen Resiko dalam Peningkatan Efektivitas Pembelajaran di Sekolah Menengah Kejuruan - Suyitno

DOI: https://doi.org/10.31004/edukatif.v4i1.1768

\begin{tabular}{|c|c|c|c|c|c|c|c|}
\hline $\begin{array}{c}\text { Desai } \\
\mathbf{n}\end{array}$ & $\begin{array}{l}\text { Functi } \\
\text { on }\end{array}$ & $\begin{array}{c}\text { Potential Failure } \\
\text { Mode }\end{array}$ & $\begin{array}{c}\text { Potential Failure } \\
\text { Effect }\end{array}$ & $\begin{array}{l}\text { Se } \\
\text { ver } \\
\text { ity }\end{array}$ & $\begin{array}{c}\text { Potential Causes of } \\
\text { Failure }\end{array}$ & $\begin{array}{c}\text { Occu } \\
\text { rren } \\
\text { ce }\end{array}$ & $\begin{array}{c}\text { Risk } \\
\text { Lev } \\
\text { el }\end{array}$ \\
\hline & & & $\begin{array}{l}\text { memahami materi } \\
\text { pelajaran }\end{array}$ & & & & \\
\hline & & & $\begin{array}{l}\text { Kegagalan dalam } \\
\text { proses pendidikan }\end{array}$ & 3 & & & 6 \\
\hline \multirow[b]{2}{*}{$\mathrm{R} 4$} & \multirow{4}{*}{ Guru } & \multirow[t]{2}{*}{$\begin{array}{l}\text { Kurang kesadaran } \\
\text { akan industri }\end{array}$} & $\begin{array}{l}\text { Melakukan } \\
\text { pembelajaran } \\
\text { menekankan teori }\end{array}$ & 3 & \multirow{2}{*}{$\begin{array}{c}\text { Kompetensi guru } \\
\text { dalam pembelajaran } \\
\text { tidak didukung dengan } \\
\text { pengetahuan teknologi } \\
\text { up to date }\end{array}$} & \multirow[b]{2}{*}{2} & 6 \\
\hline & & & $\begin{array}{l}\text { Memberikan } \\
\text { materi yang tidak } \\
\text { relevan dengan } \\
\text { tehnologi terkini }\end{array}$ & 4 & & & 8 \\
\hline \multirow[t]{2}{*}{ R5 } & & \multirow[t]{2}{*}{$\begin{array}{l}\text { Background } \\
\text { pendidikan guru } \\
\text { kurang sesuai }\end{array}$} & $\begin{array}{l}\text { Tidak menguasai } \\
\text { materi yang } \\
\text { mestinya } \\
\text { disajikan } \\
\end{array}$ & 3 & \multirow{2}{*}{$\begin{array}{c}\text { Kompetensi guru } \\
\text { dalam pembelajaran } \\
\text { tidak didukung dengan } \\
\text { latar belakang } \\
\text { pendidikan }\end{array}$} & \multirow[t]{2}{*}{2} & 6 \\
\hline & & & $\begin{array}{l}\text { Motivasi guru } \\
\text { dalam mengajar } \\
\text { berkurang }\end{array}$ & 3 & & & 6 \\
\hline \multirow{3}{*}{ R6 } & \multirow{9}{*}{$\begin{array}{l}\text { Kuriku } \\
\text { lum }\end{array}$} & \multirow[t]{3}{*}{$\begin{array}{c}\text { Tidak relevan } \\
\text { dengan kebutuhan } \\
\text { industri }\end{array}$} & $\begin{array}{l}\text { Tidak sesuai } \\
\text { dengan skill yang } \\
\text { di butuhkan oleh } \\
\text { industri }\end{array}$ & 4 & \multirow{3}{*}{$\begin{array}{c}\text { Kurikulum yang } \\
\text { dipergunakan belum } \\
\text { sepenuhnya berbasis } \\
\text { link and match dengan } \\
\text { industri }\end{array}$} & \multirow{3}{*}{3} & 12 \\
\hline & & & $\begin{array}{l}\text { Kepuasan peserta } \\
\text { didik rendah }\end{array}$ & 2 & & & 6 \\
\hline & & & $\begin{array}{ll}\text { Lulusan } & \text { tidak } \\
\text { siap kerja }\end{array}$ & 3 & & & 9 \\
\hline \multirow{3}{*}{ R7 } & & $\begin{array}{c}\text { Terbatasnya } \\
\text { praktek industri }\end{array}$ & $\begin{array}{l}\text { Siswa memiliki } \\
\text { keterampilan } \\
\text { yang rendah }\end{array}$ & 3 & $\begin{array}{l}\text { Kurang menjalin } \\
\text { kerjasama dengan } \\
\text { DUDI }\end{array}$ & & 9 \\
\hline & & & $\begin{array}{lr}\text { Siswa } & \text { memiliki } \\
\text { adaptasi } & \text { dunia } \\
\text { kerja yang rendah }\end{array}$ & 3 & & 3 & 9 \\
\hline & & & $\begin{array}{ll}\text { Citra sekolah } \\
\text { menurun }\end{array}$ & 3 & & & 9 \\
\hline \multirow{3}{*}{$\mathrm{R} 8$} & & $\begin{array}{l}\text { Iklim pembelajaran } \\
\text { kurang berorientasi }\end{array}$ & $\begin{array}{l}\text { Motivasi belajar } \\
\text { siswa rendah }\end{array}$ & 3 & \multirow{3}{*}{$\begin{array}{c}\text { Pembelajaran masih } \\
\text { menekankan prestasi } \\
\text { akademik berdasarkan } \\
\text { pengetahuan teoritik }\end{array}$} & \multirow{3}{*}{3} & 9 \\
\hline & & kerja & $\begin{array}{l}\text { Tidak } \\
\text { menumbuhkan } \\
\text { lulusan siap kerja }\end{array}$ & 3 & & & 9 \\
\hline & & & $\begin{array}{l}\text { Pembelajaran } \\
\text { tidak } \\
\text { menumbuhkan } \\
\text { jiwa } \\
\text { kewirausahaan }\end{array}$ & 3 & & & 9 \\
\hline \multirow[t]{2}{*}{ R9 } & \multirow[t]{2}{*}{$\begin{array}{l}\text { Lingku } \\
\text { ngan } \\
\text { Akade } \\
\text { mik }\end{array}$} & $\begin{array}{c}\text { Jumlah siswa } \\
\text { melebihi kapasitas }\end{array}$ & $\begin{array}{l}\text { Proses } \\
\text { pembelajaran } \\
\text { tidak } \\
\text { efektif/kondusif }\end{array}$ & 3 & \multirow[t]{2}{*}{$\begin{array}{c}\text { Rekrutmen siswa baru } \\
\text { kurang } \\
\text { mempertimbangkan } \\
\text { daya tamping ideal }\end{array}$} & \multirow[t]{2}{*}{3} & 9 \\
\hline & & & Siswa akan & 3 & & & 9 \\
\hline
\end{tabular}


148 Implementasi Manajemen Resiko dalam Peningkatan Efektivitas Pembelajaran di Sekolah Menengah Kejuruan - Suyitno

DOI: https://doi.org/10.31004/edukatif.v4i1.1768

\begin{tabular}{|c|c|c|c|c|c|c|c|}
\hline $\begin{array}{c}\text { Desai } \\
\mathbf{n}\end{array}$ & $\begin{array}{l}\text { Functi } \\
\text { on }\end{array}$ & $\begin{array}{c}\text { Potential Failure } \\
\text { Mode }\end{array}$ & $\begin{array}{c}\text { Potential Failure } \\
\text { Effect }\end{array}$ & $\begin{array}{l}\text { Se } \\
\text { ver } \\
\text { ity }\end{array}$ & $\begin{array}{c}\text { Potential Causes of } \\
\text { Failure }\end{array}$ & $\begin{array}{c}\text { Occu } \\
\text { rren } \\
\text { ce }\end{array}$ & $\begin{array}{c}\text { Risk } \\
\text { Lev } \\
\text { el }\end{array}$ \\
\hline & & & $\begin{array}{l}\text { mengalami } \\
\text { kesulitan dalam } \\
\text { belajar }\end{array}$ & & & & \\
\hline \multirow{3}{*}{ R10 } & & \multirow[t]{3}{*}{$\begin{array}{c}\text { Perlengkapan } \\
\text { laboratorium/bengk } \\
\text { el kurang memadai }\end{array}$} & $\begin{array}{l}\text { Siswa akan } \\
\text { mengalami } \\
\text { kesulitan dalam } \\
\text { belajar praktek }\end{array}$ & 3 & \multirow[t]{3}{*}{$\begin{array}{l}\text { Perlengkapan bengkel } \\
\text { masih memanfaatkan } \\
\text { mesin teknologi lama }\end{array}$} & \multirow{3}{*}{3} & 9 \\
\hline & & & $\begin{array}{l}\text { Tidak sesuai } \\
\text { dengan skill yang } \\
\text { di butuhkan oleh } \\
\text { industri }\end{array}$ & 3 & & & 9 \\
\hline & & & $\begin{array}{l}\text { Proses } \\
\text { pembelajaran } \\
\text { tidak efektif }\end{array}$ & 3 & & & 9 \\
\hline \multirow{2}{*}{ R11 } & & \multirow[t]{2}{*}{$\begin{array}{c}\text { Pemanfaatan } \\
\text { fasilitas sekolah } \\
\text { kurang optimal }\end{array}$} & $\begin{array}{ll}\text { Kegiatan } & \\
\text { akademik } & \text { si } \\
\text { terganggu }\end{array}$ & 3 & \multirow[t]{2}{*}{$\begin{array}{c}\text { Beberapa pengelola } \\
\text { unit masih rangkap } \\
\text { jabatan }\end{array}$} & \multirow[t]{2}{*}{2} & 6 \\
\hline & & & $\begin{array}{l}\text { Motivasi belajar } \\
\text { siswa menurun }\end{array}$ & 3 & & & 6 \\
\hline
\end{tabular}

\section{Evaluasi Risiko}

Tahapan evaluasi risiko merupakan fungsi terpenting dari tahapanmanajemen risiko dimana jika risiko terjadi, maka risiko mana yang nantinya membutuhkan prioritas terlebih dahulu sehinga rencana mitigasi dapat di tetapkan berdasarkan data histori yang ada serta mempertimbangkan dari pendapat para ahli (Al-Jundi \& Ahmad, 2016.). Terdapat 4 level risiko berdasarkan tingkat kepentingannya, yaitu extreme risk, high risk, moderate risk, dan low risk. Apabila risiko tersebut tergolong extreme risk, maka proses mitigasi harus dilaksanakan terlebih dahulu. Apabila berada di tingkat high risk, maka proses mitigasi diprioritaskan kedua setelah extreme risk. Sedangkan pada moderate risk, proses mitigasi akan diprioritaskan ketiga setelah extreme dan high risk. Low risk dilakukan paling akhiratau bahkan bisa saja diterima (accept) karena dianggap tidak dapat dihindari ataurisiko tersebut terlalu kecil sehingga apabila dilakukan proses mitigasi akan membutuhkan biaya tambahan.

Tabel 5. Tabel Risk Matrix Pada SMK Mondoroko

\begin{tabular}{|c|c|c|c|c|c|c|}
\hline \multirow{2}{*}{$\begin{array}{l}\text { OCCUR } \\
\text { RENCE }\end{array}$} & \multicolumn{6}{|c|}{ SEVERITY } \\
\hline & 1 & 2 & 3 & 4 & & 5 \\
\hline \multicolumn{7}{|l|}{5} \\
\hline \multicolumn{7}{|l|}{4} \\
\hline 3 & & R6 & $\begin{array}{l}\mathrm{R} \\
\mathrm{R}\} \\
\mathrm{R}\end{array}$ & $\begin{array}{l}8, \mathrm{R} 6 \\
,\end{array}$ & & \\
\hline 2 & & & & $3, \mathrm{R} 1$ & & \\
\hline
\end{tabular}


149 Implementasi Manajemen Resiko dalam Peningkatan Efektivitas Pembelajaran di Sekolah Menengah Kejuruan - Suyitno

DOI: https://doi.org/10.31004/edukatif.v4i1.1768

\section{Pemetaan Level Risiko}

Setelah dilakukan penilaian terhadap risiko-risiko yang sudah teridentifikasi berdasarkan frekuensi terjadinya risiko dan dampak yang ditimbulkan, maka risiko- risiko tersebut dapat dipetakan dan diklasifikasikan ke dalam 4 kategori level risiko yaitu extreme risk, high risk, moderate risk, dan low risk. Setelah melakukan pemetaan terhadap seluruh risiko, maka penanganan risiko merupakan langkah selanjutnya untuk memilih dan menyetujui satu atau lebih dari pilihan untuk dilakukan penangan risiko berupa dihindari (avoid), dikurangi (mitigation), dialihkan (transfer), dan diterima (accept). Adapun hasil dari pemetaan risiko seperti pada tabel 6 berikut.

Tabel 6. Level Risiko Berdasarkan Nilai Risiko dan Penangannya

\begin{tabular}{|c|c|c|c|c|c|}
\hline $\begin{array}{l}\mathbf{N} \\
\mathbf{o}\end{array}$ & Kategori & Risiko & $\begin{array}{l}\text { Level } \\
\text { Resiko }\end{array}$ & $\begin{array}{c}\text { Jenis } \\
\text { penangana } \\
\mathbf{n}\end{array}$ & Penanganan Resiko \\
\hline 1 & Siswa & $\begin{array}{l}\text { Tidak cakap dan kurang } \\
\text { kreatif }\end{array}$ & high risk & Mitigation & $\begin{array}{l}\text { Penerapan pembelajaran } \\
\text { metode work based learning } \\
\text { (WBL) }\end{array}$ \\
\hline 2 & Siswa & $\begin{array}{l}\text { Kurangnya pengetahuan } \\
\text { dan ketrampilan siswa }\end{array}$ & $\begin{array}{l}\text { High } \\
\text { Risk }\end{array}$ & Mitigation & $\begin{array}{l}\text { Memperbanyak sumber } \\
\text { informasi dan meningkatkan } \\
\text { keinginan belajar }\end{array}$ \\
\hline 3 & Siswa & Motivasi belajar kurang & high risk & Mitigation & $\begin{array}{l}\text { Penerapan pembelajaran } \\
\text { metode work based learning } \\
\text { (WBL) dan Student Centered } \\
\text { Learning (SCL) }\end{array}$ \\
\hline 4 & Guru & $\begin{array}{l}\text { Kurang kesadaran akan } \\
\text { industri }\end{array}$ & $\begin{array}{l}\text { High } \\
\text { Risk }\end{array}$ & Mitigation & $\begin{array}{l}\text { Menyelenggarakan program } \\
\text { guru magang industri }\end{array}$ \\
\hline 5 & Guru & $\begin{array}{l}\text { Background pendidikan } \\
\text { guru kurang sesuai }\end{array}$ & $\begin{array}{l}\text { Moderat } \\
\text { Risk }\end{array}$ & Accept & $\begin{array}{l}\text { Memfasilitasi diklat dan } \\
\text { workshop bagi guru }\end{array}$ \\
\hline 6 & Kurikulum & $\begin{array}{l}\text { Tidak relevan dengan } \\
\text { kebutuhan industri }\end{array}$ & $\begin{array}{l}\text { Extrem } \\
\text { Risk }\end{array}$ & Mitigation & $\begin{array}{l}\text { Sinkronisasi kurikulum link } \\
\text { and match dengan DUDI }\end{array}$ \\
\hline 7 & Kurikulum & $\begin{array}{l}\text { Terbatasnya praktek } \\
\text { industri }\end{array}$ & $\begin{array}{l}\text { High } \\
\text { Risk }\end{array}$ & Mitigation & $\begin{array}{llr}\text { Menjalin } & \text { hubungan } & \text { dan } \\
\text { kerjasama } & \text { dengan } & \text { DUDI } \\
\text { yang sehat } & & \\
\end{array}$ \\
\hline 8 & Kurikulum & $\begin{array}{lr}\text { Iklim } & \text { pembelajaran } \\
\text { kurang } & \text { berorientasi } \\
\text { kerja } & \end{array}$ & $\begin{array}{l}\text { High } \\
\text { Risk }\end{array}$ & Mitigation & $\begin{array}{lll}\text { Penyesuaian } & & \text { Standar } \\
\text { Kompetensi di } & \text { sekolah } \\
\text { dengan dunia } & \text { kerja } & \text { secara } \\
\text { berkelanjutan } & & \\
\end{array}$ \\
\hline 9 & $\begin{array}{l}\text { Lingkunga } \\
\mathrm{n} \text { akademik }\end{array}$ & $\begin{array}{l}\text { Jumlah siswa melebihi } \\
\text { kapasitas }\end{array}$ & $\begin{array}{l}\text { High } \\
\text { Risk }\end{array}$ & Mitigation & $\begin{array}{l}\text { Menyesuaikan rekrutmen } \\
\text { siswa baru dengan kapasitas } \\
\text { yang sesuai }\end{array}$ \\
\hline 10 & $\begin{array}{l}\text { Lingkunga } \\
\mathrm{n} \text { akademik }\end{array}$ & $\begin{array}{l}\text { Perlengkapan } \\
\text { laboratorium/bengkel } \\
\text { kurang memadai }\end{array}$ & $\begin{array}{l}\text { High } \\
\text { Risk }\end{array}$ & Mitigation & $\begin{array}{l}\text { Pengadaan peralengkapan } \\
\text { bengkel yang sesuai dengan } \\
\text { teknologi terkini }\end{array}$ \\
\hline 11 & $\begin{array}{l}\text { Lingkunga } \\
\mathrm{n} \text { akademik }\end{array}$ & $\begin{array}{l}\text { Pemanfaatan fasilitas } \\
\text { sekolah kurang optimal }\end{array}$ & $\begin{array}{l}\text { Moderat } \\
\text { Risk }\end{array}$ & Accept & $\begin{array}{l}\text { Melakukan regulasi SOP } \\
\text { pada seluruh unit pelayanan } \\
\text { sekolah }\end{array}$ \\
\hline
\end{tabular}

Berdasarkan hasil dari penilaian resiko, maka dapat dijelaskan bahwa pelaksanaan pembelajaran di SMK Mondoroko terdapat 4 resiko yang berdampak sangat signifikan atau katastropik dengan prioritas resiko seperti tergambar dalam table berikut. 
Tabel 7. Pernyataan Risiko dan Prioritas

\begin{tabular}{|c|c|c|}
\hline Pernyataan resiko & Kategori Dampak & Prioritas \\
\hline Tidak relevan dengan kebutuhan industri & Kurikulum & 1 \\
\hline Tidak cakap dan kurang kreatif & Siswa & 2 \\
\hline Kurang kesadaran akan industri & Guru & 3 \\
\hline $\begin{array}{l}\text { Perlengkapan laboratorium/bengkel kurang } \\
\text { memadai }\end{array}$ & $\begin{array}{l}\text { Lingkungan } \\
\text { Akademik }\end{array}$ & 4 \\
\hline
\end{tabular}

Tabel 7 tersebut diatas menunjukkan bahwa terdapat 4 (empat) resiko yang telah teridentifikasi berdampak signifikan yakni dari kategori kurikulum dengan risiko "Tidak relevan dengan dunia industri" menduduki prioritas pertama. Selanjutnya dari kategori siswa dengan risiko "tidak cakap dan kurang kreatif" menduduki prioritas kedua yang disusul dari kategori guru dengan risiko "kurang kesadaran akan industri" pada prioritas ketiga. Prioritas keempat dari kategori Lingkungan akademik dengan risiko "perlengkapan laboratorium/bengkel kurang memadai".

Berdasarkan hasil pemetaan risiko, kategori kurikulum dengan risiko yang ditunjukkan karena "Tidak relevan dengan dunia industri" menduduki level extrem risk, yang berarti bahwa resiko ini memiliki prioritas utama untuk dikelola. Kurikulum harus memuat standar kompetensi lulusan yang terstruktur dalam kompetensi utama, pendukung dan lain-lain yang mendukung pencapaian tujuan, pelaksanaan misi, dan perwujudan visi program studi. Hal ini sejalan dengan penelitian yang dilakukan oleh (Arianty \& Purwanto, 2018) yang menyatakan bahwa kurikulum disusun sesuai dengan standar kompetensi lulusan yang terstruktur dalam kompetensi utama, kompetensi penunjang dan kompetensi lain yang mendukung tercapainya tujuan, pelaksanaan misi, dan realisasi visi dari program studi. Hasil penelitian yang dilaukan oleh Asfiyanur et al., (2018) juga menyatakan bahwa sesuai dengan tujuan pendidikan vokasi untuk menghasilkan lulusan yang memiliki keterampilan sesuai dengan kebutuhan dunia kerja, maka diperlukan kurikulum yang relevan dengan kebutuhan dunia pekerjaan. Kolaborasi antara dunia pendidikan, lembaga pemerintah dan lembaga industri (link and match) sangat penting dan sangat diperlukan dalam proses penyusunan kurikulum pendidikan kejuruan, sehingga desain kurikulum yang dihasilkan adalah sesuai dan proporsional dengan kebutuhan dunia kerja (Tamrin et al., 2018; (Ali et al., 2020). Pada hakikatnya konsep link and match dapat digunakan sebagai media untuk meningkatkan relevansi pendidikan vokasional dengan kebutuhan tenaga kerja. Sekolah Menengah Kejuruan perlu melakukan kerjasama sinergis dengan dunia kerja profesional agar relevansi pendidikan dapat ditingkatkan dari waktu ke waktu tentunya dengan prinsip kerja dimana perguruan tinggi harus mampu memberikan keuntungan juga bagi dunia usaha, jika akan melakukan program link and match (Azman et al., 2020).

Risiko selanjutnya adalah dari kategori siswa yakni "tidak cakap dan kurang kreatif". Kemampuan berpikir kreatif menurut Rachmawati \& Kurniati dalam (Guntur \& Aliyyatunnisa, 2020) pada dasarnya merupakan sebuah potensi alamiah yang telah tertanam dalam diri manusia itu sendiri. Artinya setiap manusia memiliki potensi untuk menjadi kreatif. Tetapi, seiring dengan proses kehidupan yang dialaminya potensi kreatif tersebut dapat semakin berkembang atau semakin hilang. Sehingga manusia perlu mengoptimalkan potensi yang telah ada dengan memunculkan lingkungan yang dapat mendukung berkembangnya potensi kemampuan berpikir kreatif. Kreatifitas merupakan suatu kemampuan untuk menghasilkan sesuatu yang baru, baik baru bagi dirinya maupun orang lain. Belajar kreatif adalah siswa proses belajar merencanakan, melaksanakan dan membuktikan sendiri percobaan-percobaan. Mereka berusaha mencari hubungan antara konsep-konsep yang baru dan konsep-konsep yang telah pada struktur kognitifnya (Setiawan et al., 2018). Dalam kaitan ini, penanganan resiko "tidak cakap dan kurang kreatif" dilakukan dengan penerapan pembelajaran metode work based learning (WBL) yang berfokus pada pengembangan profesionalitas peserta didik di tempat kerja dan memberi kesempatan paserta didik untuk fokus pada evolusi mereka sendiri dan mengambil langkah selanjutnya menuju karier yang cerah. Hal ini sejalan dengan penelitian yang dilakukan 
151 Implementasi Manajemen Resiko dalam Peningkatan Efektivitas Pembelajaran di Sekolah Menengah Kejuruan - Suyitno

DOI: https://doi.org/10.31004/edukatif.v4i1.1768

oleh Sudjimat \& Permadi (2019) yang menyatakan motivasi berprestasi siswa kelompok yang diajar dengan model WBL dengan konsep pembelajaran layanan lebih tinggi daripada motivasi berprestasi kelompok siswa yang diajar dengan menggunakan TWI (Training Within Industry) model.

Kategori guru yang memiliki risiko "Kurang kesadaran akan industri" memiliki keterkaitan dengan kategori lingkungan akademik dengan risiko "Perlengkapan laboratorium/bengkel kurang memadai". Salah satu pemegang kendali optimalisasi pembelajaran vokasi adalah keberadaan dan kesiapan kompetensi guru produktif ini. Hal ini sejalan dengan penelitian yang dilakukan Sitorus, (2021) yang menyatakan bahwa peningkatan kompetensi guru produktif merupakan upaya yang harus dilakukan untuk meningkatkan keahlian yang maksimal dalam mutu pembelajaran peserta didik di sekolah kejuruan. Hal ini berdampak pada peningkatan kemampuan dan keahlian peserta didik. Kemampuan kompetensi guru produkif di SMK merupakan kunci utama bagi keberlangsungan proses pembelajaran yang berdampak pada keluarannya adalah peserta didik yang kompeten. Sekolah Menengah Kejuruan pada dasarnya tidak hanya diperuntukkan untuk memahami penguasaan teori saja, namun harus juga memiliki kompetensi teori dan praktik dalam memenuhi kriteria unjuk kerja. Hasil penelitian ini juga sejalan dengan penelitian yang dilakukan oleh Nurulpaik et al., (2021) yang menyatakan bahwa guru memiliki peranan sangat penting dalam penguasaan dan pengelolaan bengkel. Bengkel/laboratorium di SMK merupakan sarana belajar untuk mensimulasikan pekerjaan sebagaimana kegiatan yang dilakukan oleh karyawan di industry. Menurut Djojonegoro dalam (Erawati et al., 2019), pendidikan kejuruan diarahkan untuk mempersiapkan siswa memasuki lapangan kerja dan pendidikan kejuruan memerlukan fasilitas yang mutakhir untuk praktik. Fasilitas bengkel merupakan salah satu faktor dari luar yang mendukung peningkatan motivasi dan hasil belajar praktik siswa. Penanganan risiko atas kurangnya kesadaran akan industri dari kategori guru dilakukan dengan mengadakan inovasi atau pembaharuan system pendidikan dan latihan untuk guru produktif SMK dalam meningkatkan profesionalitasnya, yang salah satunya melalui apprenticeship teacher atau magang guru terutama untuk guru produktif SMK yang didesain bersama DUDI. Hal ini menguatkan penelitian yang dilakukan oleh Dwi Agus Sudjimat (2016) yang menyatakan bahwa salah satu bentuk dari pendidikan dan pelatihan guru adalah program magang industri. Program magang industri adalah pelatihan yang dilaksanakan di in-dustri yang relevan dalam rangka meningkatkan kompetensi professional guru.

Berdasarkan temuan dan pembahasan di atas, menunjukkan bahwa formulasi manajemen risiko yang muncul dan diimplmentasikan di SMK Mondoroko dilakukan atas dasar landasan teoritis dan operasional yang kuat sehingga menawarkan beberapa mitigasi yang dipandang cukup strategis dalam menguraikan permasalahan-permasalan yang timbul terkait proses pembelajaran. Hal ini berimplikasi pada pergeseran risiko dari proses pengelolaan risiko secara individual ke pengelolaan risiko secara terstruktur dengan kerangka holistik pada proses pembelajaran di SMK Mondoroko. Desain penelitian seperti ini yang dilaksanakan dengan merujuk pada tahapan proses manajemen risiko ISO 31000 pada lembaga pendidikan belum banyak dilakukan apalagi di sekolah dengan jenis vokasional.

\section{KESIMPULAN}

Analisis risiko pada proses pembelajaran di SMK Mondoroko ditinjau dari 4 kategori yakni kategori siswa, kategori guru, kategori kurikulum dan kategori lingkungan akademik. Berdasarkan keempat kategori tersebut memunculkan 29 risiko yang diidentifikasi dalam proses penilaian risiko dan berdampak signifikan secara berurutan adalah dari kategori kurikulum dengan risiko "Tidak relevan dengan dunia industri", kategori siswa dengan risiko "tidak cakap dan kurang kreatif", kategori guru dengan risiko "kurang kesadaran akan industri” dan kategori Lingkungan akademik dengan risiko "perlengkapan laboratorium/bengkel kurang memadai". Berdasarkan hasil temuan penelitian ini, risiko dari kategori kurikulum dilakukan penanganan melalui sinkronisasi kurikulum link and match dengan DUDI, risiko dari siswa dilakukan penanganan melalui 
152 Implementasi Manajemen Resiko dalam Peningkatan Efektivitas Pembelajaran di Sekolah Menengah Kejuruan - Suyitno

DOI: https://doi.org/10.31004/edukatif.v4i1.1768

penerapan pembelajaran metode work based learning (WBL), risiko dari kategori guru dilakukan penanganan melalui penyelenggaraan program guru magang industri, dan risiko dari lingkungan akademik dilakukan penanganan melalui pengelolaan dan pengadaan peralengkapan bengkel yang sesuai dengan teknologi terkini.

\section{DAFTAR PUSTAKA}

Ali, M., Mardapi, D., \& Koehler, T. (2020). Identification Key Factor In Link And Match Between Technical And Vocational Education And Training With Industry Needs In Indonesia. Proceedings Of The International Conference On Online And Blended Learning 2019 (Icobl 2019). International Conference On Online And Blended Learning 2019 (Icobl 2019), Yogyakarta, Indonesia. Https://Doi.Org/10.2991/Assehr.K.200521.053

Al-Jundi, S. A., \& Ahmad, R. (N.D.). Risk Management Model For Al-Ain University Of Science \& Technology, Uae. 18.

Arianty, F., \& Purwanto, T. A. (2018). A Review Of Vocational Education Curriculum In Accordance With Industrial Needs: Case Study. Kne Social Sciences, 3(11), 15 Https://Doi.Org/10.18502/Kss.V3i11.2747

Asfiyanur, E. P., Sumardi, K., Rahayu, Y., \& Putra, R. C. (2018). The Relevance Of Vocational High School Curriculum With The Requirement Of The Heavy Equipment Industries. Iop Conference Series: Materials Science And Engineering, 306, 012037. Https://Doi.Org/10.1088/1757899x/306/1/012037

Aven, T. (2016). Risk Assessment And Risk Management: Review Of Recent Advances On Their Foundation. European Journal Of Operational Research, 253(1), 1-13. Https://Doi.Org/10.1016/J.Ejor.2015.12.023

Azman, A., Simatupang, W., Karudin, A., \& Dakhi, O. (2020). International Journal Of Multi Science. 1(6), 10.

Dwi Agus Sudjimat, S. (2016). Magang Industri Untuk Meningkatkan Relevansi Kompetensi Profesional Guru Produktif Smk. Teknologi Dan Kejuruan, 36(2), 171-182.

Erawati, M. S., Darlius, D., \& Syofii, I. (2019). Pengaruh Fasilitas Bengkel Dan Motivasi Belajar Terhadap Hasil Belajar Teknik Pemesinan Bubut Siswa Kelas Xi Di Smk Negeri 7 Palembang. Jurnal Pendidikan Teknik Mesin, 6(1), 77-84. Https://Doi.Org/10.36706/Jptm.V6i1.6966

Guntur, M., \& Aliyyatunnisa, A. (2020). Kemampuan Berpikir Kreatif, Kritis, Dan Komunikasi Matematika Siswa Dalam Academic-Contructive Controversy (Ac). 3, 8.

Korechkov, Y. V. (2021). Institutional Support Of The Competitive Educational Environment. Journal Of Regional And International Competitiveness, $48-54$. Https://Doi.Org/10.52957/27821927_2021_2_48

Nurulpaik, I., Hasbullah, H., Purmana, W., \& Ardiansyah, N. P. (2021). Pelatihan Manajemen Bengkel/Laboratorium Bagi Guru Mata Pelajaran Praktik Di Smk Wilayah Kabupaten Pandeglang. Jurnal Ilmiah Teknologi Infomasi Terapan, 7(1), 59-63. Https://Doi.Org/10.33197/Jitter.Vol7.Iss1.2020.497

Peng, Z., P., W. (2015). An Approach Towards Global Standardization Of The Risk Matrix. Journal Of Space Safety Engineering, 2(1), 31-38.

Pradesa, H. A., Purba, C. O., \& Priatna, R. (2021). Menilai Risiko Dari Organisasi Yang Bertransformasi: Pelajaran Terbaik Untuk Penguatan Akuntabilitas Pendidikan Tinggi Di Indonesia. Jurnal Akuntabilitas Manajemen Pendidikan, 9(2), 13.

Setiawan, H., Setiany, E. P., \& Andiarani, M. (2018). Meningkatkan Kemampuan Berpikir Kreatif Matematik Siswa Sekolah Menengah Kejuruan Melalui Model Pembelajaran Inquiry Guided. 2, 7. 
153 Implementasi Manajemen Resiko dalam Peningkatan Efektivitas Pembelajaran di Sekolah Menengah Kejuruan - Suyitno

DOI: https://doi.org/10.31004/edukatif.v4i1.1768

Sitorus, J. (2021). Pemenuhan Guru Produktif Smk Di Era Revolusi Industri 4.0. Inovasi, 18(1), 9-19. Https://Doi.Org/10.33626/Inovasi.V18i1.335

Spichak, I. V., Kucheryavenko, S. A., Polevoy, I. N., \& Nazarova, A. N. (2020.). Implementation Of Risk Management In The Quality Management System Of An Educational Organization. 9.

Sudjimat, D. A., \& Permadi, L. C. (2019). Effect Of Work-Based Learning Model On Students' Achievement Motivation. Jurnal Pendidikan Teknologi Dan Kejuruan, 25(2), 204-212. Https://Doi.Org/10.21831/Jptk.V25i2.24416

Suyitno, Suyitno. (2018). Metode Penelitian Kualitatif: Konsep, Prinsip Dan Operasionalnya (1st Ed., Vol. 1). Akademia Pustaka. Https://Www.Researchgate.Net/Publication/326957100_

Tamrin, A. G., Slamet, S., \& Soenarto, S. (2018). The Link And Match Of The Demand And Supply For Productive Vocational School Teachers With Regard To Spectrum Of Vocational Skills In The Perspective Of Education Decentralization. Jurnal Pendidikan Vokasi, 8(1), 40. Https://Doi.Org/10.21831/Jpv.V8i1.15135 